\title{
Association of SLC26A4 muations with clinical features and thyroid function in deaf infants with enlarged vestibular aqueduct
}

\author{
Satoshi Iwasaki · Koji Tsukamoto $\cdot$ Shinichi Usami • \\ Kiyoshi Misawa $\cdot$ Kunihiro Mizuta $\cdot$ Hiroyuki Mineta
}

Received: 27 April 2006/ Accepted: 2 June 2006/Published online: 19 August 2006

(C) The Japan Society of Human Genetics and Springer-Verlag 2006

\begin{abstract}
Pendred syndrome and non-syndromic recessive deafness associated with enlarged vestibular aqueduct (NSRD with EVA) are caused by mutations in the SLC26A4 (PDS) gene. Unlike NSRD with EVA, Pendred syndrome is characterized by goiter, which may be present after early adulthood. However, the clinical diagnosis of these two disorders is difficult in deaf children. Expression of the SLC26A4 gene may be responsible for iodide transport in the thyroid as well as for formation and function of the inner ear. Here, we analyzed the SLC26A4 gene and performed thyroid function tests (FT3, FT4, TSH, and Thyroglobulin) on six congenitally deaf infants (mean age 2.7 years) with EVA. Mutation of the SLC26A4 gene was identified in five patients: four were compound heterozygous $(\mathrm{H} 723 \mathrm{R} / 919-2 \mathrm{~A}>\mathrm{G}, \quad \mathrm{H} 723 \mathrm{R} / \mathrm{IVS} 15+5 \mathrm{G}>\mathrm{A}, \quad \mathrm{H} 723 \mathrm{R} /$ R581S, IVS7-2A $>$ G/IVS $8+1 G>A$ ), the fifth had a frameshift mutation (322delC). All the patients demonstrated an elevation of serum thyroglobulin level. FT3 level was elevated in four of the five patients. The patient who did not have a detectable gene mutation showed normal thyroid function. We conclude that the mutations in the SLC26A4 gene identified here are highly associated with high serum thyroglobulin levels
\end{abstract}

S. Iwasaki $(\bowtie) \cdot$ K. Misawa $\cdot$ K. Mizuta $\cdot$ H. Mineta Department of Otolaryngology,

Hamamatsu University School of Medicine,

1-20-1, Handayama, Hamamatsu city 431-3192, Japan

e-mail: iwasaki@hama-med.ac.jp

K. Tsukamoto $\cdot$ S. Usami

Department of Otolaryngology,

Shinshu University School of Medicine, Shinshu, Japan in congenital and deafness infants. These mutations may be of value for the diagnosis of Pendred syndrome and NSRD with EVA.

Keywords Deafness - Pendred syndrome - SLC26A4 · Thyroid $\cdot$ Thyroglobulin

\section{Introduction}

Epidemiological surveys have shown that about $50 \%$ of cases of childhood deafness can be attributed to genetic causes (Morton 1991). Pendred syndrome, first described in 1986 (Pendred 1986), is characterized by congenital sensorineural hearing loss (SNHL) and goiter. It is an autosomal-recessive disorder caused by mutation in the SLC26A4 (PDS) gene (Everett et al. 1997). In addition to Pendred syndrome, mutations of this gene are also responsible for non-syndromic recessive deafness (NSRD) with enlarged vestibular aqueduct (EVA), or Mondini dysplasia (Usami et al. 1999). Overall, SLC26A4 mutations may account for between 5 and $10 \%$ of patients with prelingual hearing loss (Gorlin 1995). The gene is located on chromosome 7q22-q31 and encodes a chloride-iodide transporter that is expressed in the thyroid, inner ear, and kidney. The gene has 21 exons that encode a 780 amino acid protein called pendrin, a $73 \mathrm{kDa}$ glycoprotein with 11 or 12 transmembrane domains. More than 60 different SLC26A4 mutations have been identified in individuals with Pendred syndrome or NSRD with EVA (Park et al. 2003), suggesting that some of the variability in clinical expression of these syndrome is correlated with mutation genotype (Tsukamoto et al 
2003). The majority of the mutations are missense substitutions that often result in the formation of a truncated protein, but intronic mutations affecting splice sites also seem to be a frequent cause of Pendred syndrome and NSRD with EVA (Massa et al. 2003; Yang et al. 2005).

The hearing loss is sensorineural, profound and prelingual, although there may be a history of fluctuating progressive hearing loss. In the inner ear, pendrin is expressed in the endolymphatic duct and sac, regulating endolymph secretion and absorption. Pendrin defects result in neuroepithelial damage and can cause inner ear malformations (Everett et al. 1999). Thyroid dysfunction is variable, ranging from normal function to hypothyroidism and from normal thyroid volume through slight enlargement to the presence of a large multinodular goiter. It is difficult to distinguish from Pendred syndrome and NSRD in young children since the goitrous phenotype is not usually evident until adolescence. Goiter usually develops in late childhood to early adulthood and may be present in euthyroid individuals, but hypothyroidism is found in about onethird of patients with Pendred syndrome (Campbell et al. 2001). Mutation of the SLC26A4 gene may induce dysfunction of the thyroid gland, leading to the accumulation and retention of iodide in the follicular lumen where thyroglobulin is stored, and incorporate iodide during synthesis of thyroid hormone (Giraud et al. 2005). However, most patients with Pendred syndrome remain euthyroid, although they may give an abnormal result after perchlorate challenge.

A goiter is not an essential diagnostic feature of Pendred syndrome. Moreover, the perchlorate challenge test cannot be performed in deaf infants with EVA. In this study, we screened six congenitally deaf infants with EVA for mutation in the SLC26A4 gene. We also tested their serum thyroid function in order to determine whether there is a correlation between genotype and hearing loss and thyroid function phenotypes.

\section{Materials and methods}

\section{Subjects and clinical evaluation}

We studied six patients affected by congenital SNHL with EVA (Table 1). Four of the affected patients were males. The age range was $0.8-4.11$ years (mean 1.74 years) at the time of admission to our hospital and genetic testing. In all patients, a bilateral SNHL was diagnosed by auditory brainstem response (ABR) and conditioned orientated response (COR) tests; no goiters were detected by palpation. The degree of SNHL ranged from severe or profound. Mild language disturbance was observed in patients $1,2,3$, and 4 . Patients 5 and 6 had severe language disturbance, and they received cochlear implants at age 2.11 and 4.0 years, respectively. Thyroid function tests were performed for thyroid-stimulating hormone (TSH), free triiodothyronine (FT3), free thyroxine (FT4), thyroglobulin, but the perchlorate test was not used. The age range was 1.8-5.1 years (mean 2.68 years) at the time of the thyroid function analyses. The serum concentrations of thyroid hormones were determined using the ECL-IA method. The parents of the six children showed no evidence of the SNHL or thyroid disease.

In all patients, the presence of malformations of the cochlea and vestibular aqueduct was evaluated by high-resolution CT of the temporal bones and fast spinecho $\mathrm{T}_{2}$-weighted MRI (Fig. 1). The criterion for diagnosis of EVA from thin section CT was a diameter greater than $1.5 \mathrm{~mm}$ at the midpoint between the common crus and the external aperture.

DNA was extracted by standard methods from whole blood of all patients and, where available, their parents. The parents of all patients gave informed consent for the genetic analysis, which was approved by the ethical committee of Hamamatsu University School of Medicine.

\section{Mutation analysis}

Mutations were detected by a combination of intronic polymerase chain reaction (PCR) amplification, using primers flanking each exon, and sequencing of the amplification products. Exons 1-21 of the SLC26A4 gene were amplified from a genomic DNA samples by PCR. Amplification was carried out in a Perkin-Elmer thermal cycler using the following conditions: 5-min denaturation at $95^{\circ} \mathrm{C}, 37$ three-step cycles $\left(95^{\circ} \mathrm{C}\right.$ for 30 $\mathrm{s}, 55^{\circ} \mathrm{C}$ for $1 \mathrm{~min}, 72^{\circ} \mathrm{C}$ for 1 or $3 \mathrm{~min}$ ), $72^{\circ} \mathrm{C}$ for $10 \mathrm{~min}$, and ending with a holding period at $4^{\circ} \mathrm{C}$. The PCR products were directly sequenced after removal of unincorporated dNTPs and primers by incubation of 50-100 ng PCR product at $37^{\circ} \mathrm{C}$ for $30 \mathrm{~min}$ with $0.1 \mu \mathrm{l}$ exonuclease I (Amersham Life Science, Cleveland, USA) and $1 \mu \mathrm{l}$ shrimp alkaline phosphatase (Amersham Life Science). The enzymes were heat-inactivated at $80^{\circ} \mathrm{C}$ for $15 \mathrm{~min}$. An aliquot of $6 \mathrm{pmol}$ of either the forward or the reverse primer was used in standard cycle sequencing reactions with ABI Big Dye terminators, and run on an ABI 377 sequencer. 
Table 1 Clinical data among the six infants with congenital hearing loss and enlarged vestibular aqueduct

\begin{tabular}{|c|c|c|c|c|c|c|c|c|c|}
\hline Case & $\begin{array}{l}\text { Age } \\
\text { (years) }\end{array}$ & Sex & CT & & $\begin{array}{l}\text { Onset of } \\
\text { SNHL }\end{array}$ & $\begin{array}{l}\text { Degree of } \\
\text { SNHL }\end{array}$ & $\begin{array}{l}\text { Progression } \\
\text { or fluctuation } \\
\text { of SNHL }\end{array}$ & Goiter & Others \\
\hline 1 & 2 & M & EVA & $\begin{array}{l}\text { R: } 3.0 \mathrm{~mm} \\
\text { L:3.0 mm } \\
\text { Mondini (+) }\end{array}$ & Congenital & $\begin{array}{l}93 \mathrm{~dB} \\
(\mathrm{COR})\end{array}$ & $\begin{array}{l}\text { Progression } \\
\text { Fluctuation }\end{array}$ & - & $\begin{array}{l}\text { Cochlear implant } \\
\text { Vertigo (+) } \\
\text { ABR:100 dB (-) }\end{array}$ \\
\hline 2 & 1.1 & M & EVA & $\begin{array}{l}\mathrm{R}: 5.0 \mathrm{~mm} \\
\mathrm{~L}: 4.5 \mathrm{~mm} \\
\text { Mondini (-) }\end{array}$ & Congenital & $\begin{array}{l}73 \mathrm{~dB} \\
(\mathrm{COR})\end{array}$ & Fluctuation & - & $\begin{array}{l}\text { Vertigo (+) } \\
\text { Asthma } \\
\text { ABR:L90 dB, R100 dB(-) }\end{array}$ \\
\hline 3 & 1.1 & $\mathrm{~F}$ & EVA & $\begin{array}{l}\text { R: } 4.0 \mathrm{~mm} \\
\text { L: } 3.0 \mathrm{~mm} \\
\text { Mondini }(-)\end{array}$ & Congenital & $\begin{array}{l}94 \mathrm{~dB} \\
(\mathrm{COR})\end{array}$ & Fluctuation & - & $\begin{array}{l}\text { Vertigo (-) } \\
\text { ABR:100 dB (-) }\end{array}$ \\
\hline 4 & 4.1 & $\mathrm{~F}$ & EVA & $\begin{array}{l}\mathrm{R}: 4.0 \mathrm{~mm} \\
\mathrm{~L}: 4.5 \mathrm{~mm} \\
\text { Mondini (-) }\end{array}$ & Congenital & $\begin{array}{l}\text { R: } 95 \mathrm{~dB} \\
\text { L: } 98 \mathrm{~dB}\end{array}$ & Fluctuation & - & $\begin{array}{l}\text { Vertigo (-) } \\
\text { ABR:100 dB (-) }\end{array}$ \\
\hline 5 & 1.3 & M & EVA & $\begin{array}{l}\text { R: } 6.0 \mathrm{~mm} \\
\text { L: } 5.5 \mathrm{~mm} \\
\text { Mondini }(-)\end{array}$ & Congenital & $\begin{array}{l}86 \mathrm{~dB} \\
(\mathrm{COR})\end{array}$ & $\begin{array}{l}\text { Progression } \\
\text { Fluctuation }\end{array}$ & - & $\begin{array}{l}\text { Cochlear implant } \\
\text { Vertigo (+) } \\
\text { ABR:L100 dB, R90 dB }\end{array}$ \\
\hline 6 & 0.8 & M & EVA & $\begin{array}{l}\text { R: } 6.0 \mathrm{~mm} \\
\text { L: } 6.0 \mathrm{~mm} \\
\text { Mondini (+) }\end{array}$ & Congenital & $\begin{array}{l}84 \mathrm{~dB} \\
(\mathrm{COR})\end{array}$ & Fluctuation & - & $\begin{array}{l}\text { Vertigo (+) } \\
\text { ABR:L100 dB(-), R100 dB }\end{array}$ \\
\hline
\end{tabular}

$E V A$ Enlarged vestibular aqueduct, $C O R$ conditioned orientated response, $A B R$ auditory brainstem response

Fig. 1 Computed tomographic scan and fast spin-echo T2-weighted MRI showing an enlarged vestibular aqueduct (EVA) (double arrow) in right ear of patient 5. * Enlarged endolymphatic sac
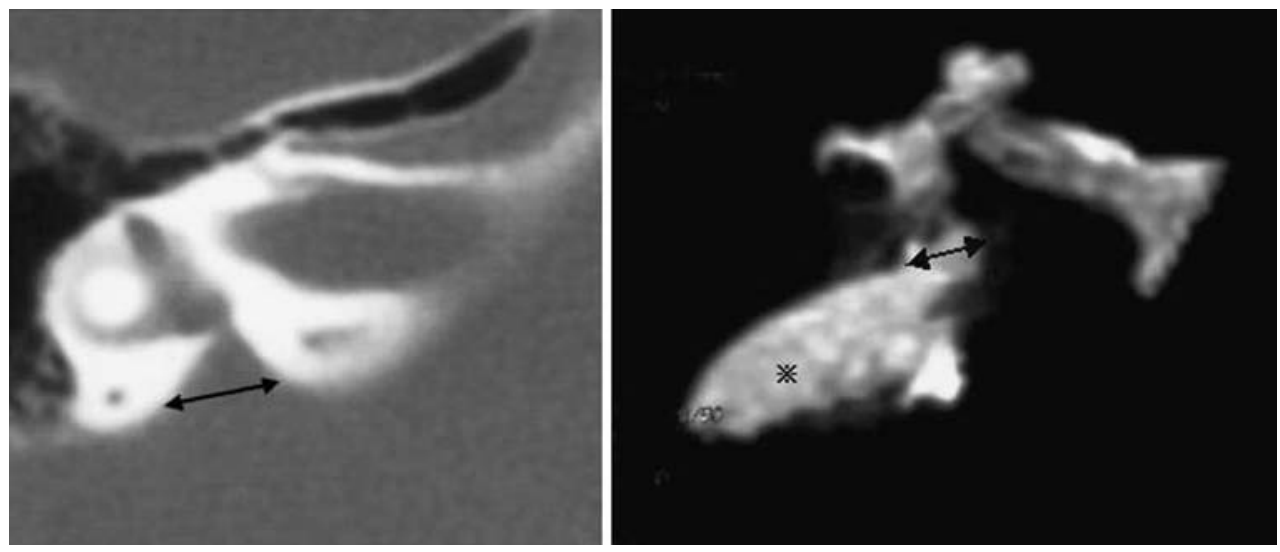

\section{Results}

Mutation analysis of the SLC26A4 gene

As a result of DNA sequence analysis (Table 2), mutations of the SLC26A4 genes were detected in five patients. Four were compound heterozygous, the fifth had a frameshift mutation. No mutations were detected in patient 4 . Four missense mutations, the four splice site mutations, and a frameshift mutation were identified in the five patients. The two compound heterozygous missense mutations were H723R $(2168 \mathrm{~A}>\mathrm{G}$ in exon 19) in patient 1, 2, 3 and R581S (1743G $>C$ in exon 16 ) in patient 3 . The four compound heterozygous splice site mutations were IVS7-2A $>\mathrm{G}$ (exon 7, acceptor splice site), IVS8+1G $>$ A (exon 8, donor splice site) in patient $6,919-2 \mathrm{~A}>\mathrm{G}$ (exon 7 , acceptor splice site) in patient 1 , and IVS15+5G $>A$ (exon 15, splice site) in patient 2 . The father of patient 6 had an IVS7$2 \mathrm{~A}>\mathrm{G}$ heterozygous mutation and his mother had an IVS $8+1 \mathrm{G}>\mathrm{A}$ heterozygous mutation. The parents were not diagnosed with SNHL nor were goiters palpated. The frameshift mutation (322delC) was found in patient 5 in exon 4 at codon 108 and led to a stop codon at position 139.

\section{Clinical features}

In all patients, the vestibular aqueduct was enlarged bilaterally with a diameter ranging from 3 to $6 \mathrm{~mm}$ (Table 1). Signal intensity ratio (sac signal/cereberospiral fluid signal) detected by MR imaging and diameter of EVA were not correlated with the mutations in the SLC26A4 gene. 
Thyroid function analysis showed (Table 3) normal serum concentrations of FT4 and TSH (normal values: $0.9-1.6 \mathrm{ng} / \mathrm{dl}, 0.5-5.0 \mathrm{mU} / \mathrm{l}$, respectively) in all patients. Mildly elevated concentration of FT3 (normal value: $2.3-4.0 \mathrm{pg} / \mathrm{ml}$ ) was shown in patients $1,3,5,6$ $(4.2-5.5 \mathrm{pg} / \mathrm{ml}$, mean $4.9 \mathrm{pg} / \mathrm{ml})$. Serum thyroglobulin levels (normal value: $1.4-78 \mathrm{ng} / \mathrm{ml}$ ) were elevated in all patients $(105-372.5 \mathrm{ng} / \mathrm{ml}$, mean $171.0 \mathrm{ng} / \mathrm{ml})$ with a detectable mutation of the SLC26A4 gene, with the exception of patient $4(72.5 \mathrm{ng} / \mathrm{ml})$.

\section{Discussion}

Mutations of the SLC26A4 (PDS) gene can cause SNHL with goiter (Pendred syndrome) or NSRD with EVA (Everett et al. 1997; Usami et al. 1999). They have also been reported to be associated with a wide range of other phenotypes. Over 60 mutations of SLC26A4 have been described to date, and include missense, nonsense, splice site, and frameshift mutations, as well as a large partial genomic deletion (Park et al. 2003). In the present study, the two missense mutations (H723R and R581S), the four splice site mutations (IVS7-2A $>$ G, IVS8+1G $>$ A, 919-2A $>$ G, and IVS15+5G $>A$ ), and a frameshift mutation (322delC)

Table 2 Mutations of SLC26A4 gene and phenotypes in six affected infants

\begin{tabular}{|c|c|c|c|}
\hline Case & Allele one & Allele two & Phenotype \\
\hline 1 & H723R & $919-2 \mathrm{~A}>\mathrm{G}$ & $\begin{array}{l}\text { Progressive NSRD with EVA } \\
\text { High Tg and FT3 }\end{array}$ \\
\hline 2 & H723R & IVS15+5G $>$ A & $\begin{array}{l}\text { NDRD with EVA } \\
\text { High Tg }\end{array}$ \\
\hline 3 & H723R & R581S & $\begin{array}{l}\text { NDRD with EVA } \\
\text { High Tg and FT3 }\end{array}$ \\
\hline 4 & $(-)$ & $(-)$ & NDRD with EVA \\
\hline 5 & $322 \mathrm{delC}$ & stop at 139 & $\begin{array}{l}\text { Progressive NSRD with EVA } \\
\text { High Tg and FT3 }\end{array}$ \\
\hline 6 & IVS7-2A $>G$ & IVS $8+1 \mathrm{G}>\mathrm{A}$ & $\begin{array}{l}\text { NDRD with EVA } \\
\text { High Tg and FT3 }\end{array}$ \\
\hline
\end{tabular}

NSRD Non-syndromic recessive deafness, EVA enlarged vestibular aqueduct, $T g$ thyroglobulin were identified in five of six patients with congenital hearing loss and EVA. Compound heterozygous missense and splice site mutations were found in four of six patients. The mutations, H723R, IVS7-2A $>\mathrm{G}$, IVS8+1G $>A$, and $322 \mathrm{delC}$, were previously reported in Japanese families with either Pendred syndrome or NSRD with EVA (Tsukamoto et al. 2003). R581S, 919$2 \mathrm{~A}>\mathrm{G}$, and IVS15+5G $>\mathrm{A}$ were novel SLC26A4 mutations. H723R and IVS7-2A $>\mathrm{G}$ are common alleles and account for the majority of SLC26A4 mutations in East Asian populations (Park et al. 2003). The distributions of mutant SLC26A4 alleles differ significantly between various ethnic populations. The mutation H723R accounts for 53\% of SLC26A4 mutation in Japanese patients, suggesting a possible founder effect (Tsukamoto et al. 2003). In Caucasoid populations, the mutations IVS8+1G>A, L236P, and T416P account for nearly half of all SLC26A4 mutation alleles (Campbell et al. 2001). We speculate here that the mutations found in five of the six patients (cases 1, 2, 3, 5, and 6) contributed to the pathogenesis of Pendred syndrome or NSRD with EVA, because H723R, IVS7-2A $>\mathrm{G}$, IVS8+1G $>$ A mutations were compound heterozygous and $322 \mathrm{delC}$ caused a frameshift at codon 108 and led to a stop codon at position 139 .

The SLC26A4 gene encodes a transmembrane protein known as pendrin, which is expressed in the fetal cochlea, thyroid, and kidney. Pendrin transports chloride and iodide and mediates the exchange of chloride and formate (Fugazzola et al. 2001). The hearing loss associated with SLC26A4 mutations is thought to be related to enlargement of the vestibular aqueduct (EVA) and Mondini dysplasia (1.5 cochlear turns instead of the normal 2.5). In general, mutations of the SLC26A4 are associated with a wide range of hearing loss phenotypes, which can be profound, prelingual, and progressive, and with varying extents of EVA dilatation as envisaged by axial computed tomography. The mutations identified here did not produce a wide range of effects. The function of pendrin in the inner ear is not well understood. In the mouse, pendrin is expressed in the endolymphatic duct and sac from

Table 3 Thyroid function data (FT3, FT4, TSH, and Thyroglobulin) in six affected infants

\begin{tabular}{llllll}
\hline Case & Age (years) & FT3 $(2.3-4.0 \mathrm{pg} / \mathrm{ml})$ & FT4 (0.9-1.6 ng/dl) & TSH (0.5-5.0 mU/l) & $\begin{array}{l}\text { Thyroglobulin } \\
(1.4-78 \mathrm{ng} / \mathrm{ml})\end{array}$ \\
\hline 1 & 2 & 5.3 & 1.5 & 1.38 & 130.1 \\
2 & 2.2 & 3.8 & 1.4 & 1.75 & 1.68 \\
3 & 3.2 & 4.9 & 1.1 & 2.89 & 139 \\
4 & 5.1 & 4 & 1.1 & 2.06 & 72.5 \\
5 & 1.8 & 5.1 & 1.2 & 1.43 & 117.5 \\
6 & 1.8 & 4.2 & 1.2 & & 105 \\
\hline
\end{tabular}


embryonic day 13 onwards, and in non-sensory parts of the utricle, saccule and cochlea (Everett et al. 1999). At present, iodide is not known to have an important role in the inner ear, whereas a role for chloride can be readily postulated. A loss of chloride transport within the inner ear could lead to abnormal endolymph composition, resulting in toxic and osmotic mechanisms damaging the neuroepithelium and enlarging the membranous labyrinth structures (Fugazzola et al. 2001).

Pendred syndrome is clinically differentiated from NSRD with EVA by the presence of goiter. Variability of the goiter due to other genetic and/or environmental factors has been reported (Yang et al. 2005; Scinicariello et al. 2005). When goiter is found in Pendred syndrome, it is most often euthyroidal and not evident until the second decade of life. This means that it is difficult to distinguish between Pendred syndrome and NSRD with EVA before the age of 10 years (Reardon et al. 1999). Thus, a clear correlation of SLC26A4 genotype with thyroid phenotype has not emerged. The associations of thyroid function with SLC26A4 mutations in early infancy have not been investigated, whereas it is known that malformation of inner ear is congenital and hearing loss is prelingual. Therefore, we assessed thyroid function (FT3, FT4, TSH, and thyroglobulin) in infants (mean age 2.7 years) with SLC26A4 mutations. SLC26A4 mutations were detected in five of six patients, and all showed elevation of serum thyroglobulin levels. Thyroglobulin is a 330$\mathrm{kDa}$ glycoprotein that undergoes homodimerization in the endoplasmic reticulum and other posttranslational modifications. Iodine is critical to thyroid gland function and thyroid hormone synthesis. From the follicular cell, iodide is transported by pendrin across the apical membrane. The iodide is then delivered to the cellcolloid interface where it is oxidized by thyroid peroxidase and bound to tyrosyl residues in the thyroglobulin (Giraud et al. 2005). Pendrin dysfunction may cause diminished iodide transport across the apical membrane. As a result, thyroglobulin is stored at high concentrations in the thyroid follicular lumen. Adequate nutritional iodide intake from vegetable and dairy food products (Scinicariello et al. 2005) may compensate for an iodide transport deficit, thereby maintaining the euthyroid status. In conclusion, we speculate that serum thyroglobulin level is elevated by an abnormal iodide-trapping mechanism caused by pendrin dysfunction during infancy and that thyroid function can be rescued by some genetic (Royaux et al. 2000; Dentice et al. 2005) or environmental cofactors, such as nutritionally supplied iodide, after the age of 10 years. Inadequate compensation may lead to goiter.
The identification of etiologic cofactors for NSRD with EVA before the age of 10 years would provide insight into its pathogenesis and be beneficial for diagnosis. Moreover, thyroid function and phenotypic changes would still have to be checked at regular intervals from early infancy into the second decade whether or not our hypothesis is correct. We will continue to monitor our affected patients with SLC26A4 mutations.

Acknowledgment This work was supported by the Acute Profound Deafness Research Committee of the Ministry of Health, Labour and Welfare, Tokyo, Japan.

\section{References}

Campbell C, Cucci RA, Prasad A, Green GE, Edeal JB, Galer CE, Karniski LP, Sheffield VC, Smith RJH (2001) Pendred syndrome, DFNB4, and PDS/SLC26A4 identification of eight novel mutation and possible genotype-phenotype correlations. Hum Mutat 17:404-411

Dentice M, Luongo C, Elefante A, Ambrosio R, Salzano S, Zannini M, Nitsch R, Lauro RD, Rossi G, Fenzi G, Salvatore D (2005) Pendrin is a novel in vivo downstream target gene of the TTF-1/Nkx-2.1 homeodomain transcription factor in differentiated thyroid cells. Mol Cell Biol 25:10171-10182

Everett LA, Glaser B, Beck JC, Idol JR, Buchs A, Heyman M, Adawi F, Hazani E, Nassir E, Baxevanis A, Sheffield VC, Green ED (1997) Pendred syndrome is caused by mutation in a putative sulphate transporter gene (PDS). Nat Genet 17:411-422

Everett LA, Morsli H, Wu DK, Green ED (1999) Expression pattern of the mouse ortholog of the Pendred's syndrome gene (PDS) suggests a key role for pendrin in the inner ear. Proc Natl Acad Sci USA 969:727-732

Fugazzola L, Cerutti N, Mannavola D, Vannucchi G, BeckPeccoz P (2001) The role of pendrin in iodide regulation. Exp Clin Endocr Diab 109:18-22

Giraud A, Dicristofaro J, De Micco C, Lejeune PJ, Barbaria J, Mallet B (2005) A plasminogen-like protein, oresent in the apical extracellular environment thyroid epithelial cells, degrades thyroglobulin in vitro. Biochem Biophys Res Commun338:1000-1004

Gorlin RJ (1995) Genetic hearing loss associated with endocrine and metabolic disorders. In: Gorlin RJ (ed) Hereditary hearing loss and its syndromes. Oxford University Press, New York, pp 337-339

Massa G, Jaenen N, de Varebeke SJ, Peeters N, Wuyts W (2003) Solitary thyroid nodule as presenting symptom of Pendred syndrome caused by a novel splice-site mutation in intron 8 of the SLC26A4 gene. Eur J Pediatr 162:674-677

Morton NE (1991) Genetic epidemiology of hearing impairment. Ann NY Acad Sci 630:16-31

Park HJ, Shaukat S, Liu XZ, Hahn SH, Naz S, Ghosh M, Kim HN, Moon SK, Abe S, Tukamoto K, Riazuddin S, Kabra M, Erdenetungalag R, Radnaabazar J, Khan S, Pandya A, Usami SI, Nance WE, Wilcox ER, Griffith AJ (2003) Origines and frequencies of SLC26A4 (PDS) mutations in east and south Asians: global implications for the epidemiology of deafness. J Med Genet 40:242-248

Pendred V (1986) Deaf mutism and goiter. Lancet 2:532 
Reardon W, Coffey R, Chowdhury T, Grossman A, Jan H, Britton K, Kendall-Taylor P, Trembath R (1999) Prevalence, age of onset, and natural history of thyroid disease in pendred syndrome. J Med Genet 36:595-598

Royaux IE, Suzuki K, Mori A, Katoh R, Everett LA, Kohn LD, Green ED (2000) Pendrin, the protein encoded by the Pendred syndrome gene (PDS), is an apical porter of iodide in the thyroid and is regulated by thyrogloglin in FRTL-5 cells. Endcrinology 141:839-845

Scinicariello F, Murray HE, Smith L, Wilbur S, Fowler BA (2005) Genetic factors that might lead to different responses in individuals exposed to perchlorate. Environ Health Perspect 113:1479-1484

Tsukamoto K, Suzuki H, Harada D, Namba A, Abe S, Usami S (2003) Distribution and frequencies of PDS (SLC26A4) mutations in Pendred syndrome and nonsyndromic hearing loss associated with enlarged vestibular aqueduct: a unique spectrum of mutations in Japanese. Eur J Hum Genet 11:916-922

Usami S, Abe S, Weston MD, Shinkawa H, Van Camp G, Kimberling WJ (1999) Non-syndromic hearing loss associated with enlarged vestibular aqueduct is caused by PDS mutations. Hum Genet 104:117-200

Yang JJ, Tsai CC, Hsu HM, Shiao JY, Su CC, Li SY (2005) Hearing loss associated with enlarged vestibular aqueduct and Mondini dysplasia is caused by splice-site mutation in the PDS gene. Hear Res 199:22-30 